\title{
Analysis Concept of the Blue Economy Islamic Perspective (Case Studi Jumiang as Marine Tourism in Pamekasan)
}

\author{
Fahrurrozi Fahrurrozi* \\ Institut Agama Islam Negeri Madura, Indonesia
}

Jumiang Beach is an interesting marine tourism destination in Pamekasan, Madura. This makes it possible to both improve the quality of environment and enhance local society's economic life. On the other hand, a bad effect of tourims affects environment due to the bad deed of local people and visitors in expoliting natural resource improperly. Through the principle of Blue Economy, the enhancement of ability, innovation and creativity is put into a wish to efficiently boost the use of natural tourism resource. The concept is based on some principles including creativity, innovation, local resource use, and the use of recycleable materials into the better management of natural resource. Implementation of the concept is taken from the activities of marine society of Tanjung village at the Jumiang beach consisting of 1) The efficient use of natural resource is through Low CO2 Emission and resources efficient 2) Zero - Waste which leaves no rubbish at all 3) Social solidarity in empowering local people 4) Multiple Revenue in which a person could earn from various occupation.

\section{Keywords: Blue Ecoonomy, Marine Tourism, Islamic Economy}

Pantai Jumiang merupakan pantai wisata yang menarik sehingga tergolong pariwisata bahari hal ini merupakan pengembangan dalam peningkatkan pemanfaatan lingkungan untuk pembangunan masyarakat pesisir. Salah satu dampak negatif pariwisata adalah rusaknya lingkungan diakibatkan oleh prilaku manusia yang tidak ramah dan mengeksploitasi sumber daya alam secara berlebihan. Melalui prinsip Blue Economy peningkatan kemampuan dalam berinovasi dan kreativitas diharapkan mampu mendorong pemanfaatan sumberdaya alam pariwisata secara efisien. Konsep blue economy menganut beberapa prinsip, yaitu kreativitas, inovasi, memanfaatkan sumber daya lokal, dan pemanfaatan material yang diupayakan untuk tidak menyisakan limbah dalam rangka pengelolaan sumber daya alam yang lebih baik. Implementasi dari blue economy dari aktivitas masyarakat pesisir di Desa Tanjung dalam kegiatan ekonomi pariwisata bahari Jumiang yaitu 1) Efisiensi Alam dapat dilakukan dengan cara Low CO2 Emission dan resources efficient 2) Zero - Waste kegiatan yang tidak meninggalkan sampah.3) Kepedulian Sosial dengan adanya pemberdayaan masyarakat lokal 4) Multiple Revenue satu orang penduduk pesisir bisa mendapat pendapatan yang banyak dari berbagai sumber penghasilan. 


\section{PENDAHULUAN}

Indonesia adalah negara berkembang yang tujuan pembangunan ekonomi nya untuk memeratakan pembangunan semua sektor termasuk sektor ekonomi dengan meningkatkan kesempatan kerja sehingga tercipta pemerataan pendapatan, menciptakan struktur perekonomian yang seimbang sehingga dapat mengurangi perbedaan kemampuan antar daerah. Sebagai Negara yang berkembang Indonesia masih memiliki potensi Sumber Daya Alam (SDA) luar biasa yang apabila dikelola dan dikembangkan akan menjadi komiditi yang handal untuk pembangunan ekonomi Indonesia menjadi Negara maju seperti sumber daya pesisir perikanan dan kelautan.

Sektor perikanan dan kelautan sebagai salah satu pendukung yang memiliki peran penting dalam pembangunan ekonomi Indonesia sebagai Negara kepulauan (Archipelagic country). Sektor tersebut akan memberikan nilai tambah sebagai Sumber Daya Alam (SDA) yang akan menjadi kekuatan pembangunan ekonomi nasional karena dapat memberikan kontribusi yang sangat penting terhadap pertumbuhan ekonomi. Sebagai suatu kegiatan ekonomi, perikanan dan kelautan termasuk juga pesisir perlu dikembangkan dan menjadi prioritas pembangunan ekonomi supaya mampu mewujudkan perkembangan dan pertumbuhan ekonomi yang berkelanjutan. Selain dari hal tersebut kelautan dan perikanan yang pada saat ini sudah mengarah pada industrialisasi harus bisa menjaga keberlangsungan usaha dengan tetap memperhatikan dan menjaga keseimbangan dan kelestarianya Faisyal (2015).

Keseimbangan dan kelestarian perairan dapat mengangkat dan memberikan jaminan keberlangsungan hidup kepada semua masyarakat khusunya masyarakat pesisir. Masyarakat pesisir adalah suatu kelompok masyarakat yang terdiri dari kelompok masyarakat hukum, kelompok masyarakat tradisional dan masyarakat lokal yang berdomisili di wilayah pesisir. Masyarakat tersebut hidup dan bermukim berhadapan langsung dengan laut yang memiliki kekayaan alam berlimpah akan tetapi sebagian besar masyarakat belum bisa mengangkat kelayakan hidup mereka karena beraneka ragam kekayaan laut dan pesisir masih sangat kurang dimaksimalkan potensinya untuk meningkatkan kesejahteraan masyarakat setempat. Salah satu potensi yang dapat dikembangkan dari wilayah pesisir adalah pariwisata bahari.

Pariwisata di Indonesia adalah segala sesuatu yang erkaitan dengan wisata beserta usaha-usaha yang berkaitan dibidangnya. Bagi Indonesia wilayah pesisir memiliki arti strategis karena merupakan wilayah peralihan antara ekosistem darat dan laut. Arti strategis wilayah pesisir tersebut karena memiliki sumberdaya alam yang sangat berpotensi dan jasa lingkungan yang sangat kaya sehingga dapat menibulkan daya tarik bagi berbagai pihak sebagai bentuk pemanfaatan sumberdayanya dan berbagai instansi atau lembaga untuk memuat regulasi pemanfaatannya. Sebagai salah satu regulasi pemanfaatan sumberdaya alam pesisir adalah pantai atau pariwisata bahari.

Pariwisata bahari Pariwisata bahari merupakan jenis pari- wisata yang berpengaruh besar pada pembangunan ekonomi dengan kontribusi yang sangat besar dengan penyediaan lapangan kerja baru dan dan aktivitas ekonomi lainnya (multiplier effect) serta pemasukan devisa bagi Negara Fadilah and Suprihardjo (2016). Pariwisata tersebut apabila dikembangakan dengan baik akan menjadi sektor yang berpengaruh terhadap ekonomi dan sosial masyarakat itu sendiri seperti membantu pembangunan daerah, meningkatkan pendapatan masyarakat dan lain sebagainya termasuk di daerah Pamekasan Madura seperti pantai jumiang.

Pantai Jumiang adalah salah satu pantai di Pamekasan yang berada di Desa Tanjung Kecamatan Pademawu Kabupaten Pamekasan merupakan pantai wisata yang berada di ujung timur selatan Pamekasan adalah tempat wisata yang ramai sangat indah dan dapat memberikan sensasi alam yang unik dan menarik sehingga cocok dijadikan sebagai tempat wisata keluarga atau pariwisata bahari. Kegiatan wisata ini sangat mempengaruhi pertumbuhan ekonomi masyarakat sekitar karena kegiatan pariwisata merupakan suatu proses yang kompleks didalamnya terdapat interaksi antara wisatawan, masyarakat dan sumberdaya. Salah satu dampak negatif pariwisata adalah rusaknya lingkungan diakibatkan oleh prilaku manusia baik masyarakat sekitar maupun wisatawan yang tidak ramah dan mengekpliotasi sumber daya alam secara berlebihan disamping itu sampah yang akan menjadi sumber masalah bagi sosial dan ekologi suatu kawasan tersebut. Melalui prinsip Blue Economy peningkatan kemampuan dalam berinovasi dan kreativitas diharapkan mampu mendorong pemanfaatan sumberdaya alam pariwisata secara efisien, serta berwawasan lingkungan dengan memanfaatkan limbah yang dihasilkan agar menjadi bahan baku dalam proses produksi yang kompetitif dan menguntungkan. Dari penjelasan diatas maka jurnal ini akan menjelasakan tentang analisis konsep blue ekonomi pada pariwisata bahari perspektif islam di Kabupaten Pamekasan.

\section{TINJAUAN PUSTAKA}

\section{Pariwisata Bahari}

Pariwisata Bahari (ecotourism, green tourism atau alternative tourism) merupakan wisata yang berorientasi pada lingkungan untuk menjembatani kepentingan perlindungan sumberdaya alam/lingkungan dan industri kepariwisataan. Pariwisata Bahari atau wisata Pantai adalah salah satu bentuk pemanfaatan wilayah pesisir yang kegiatannya menitik beratkan pada daerah pantai dengan memanfaatkan sumberdaya alam pantai, baik yang berada di wilayah daratannya maupun wilayah perairannya Fandeli (2000).

Dari pengertian - pengertian diatas maka bisa diambil kesimpulan tentang wisata bahari yaitu Wisata bahari adalah kegiatan untuk menikmati keindahan dan keunikan daya tarik wisata alam di wilayah pesisir yang memanfaatkan potensi alam bahari sumberdaya alam pantai, baik yang berada di wilayah daratannya maupun wilayah perairannya sebagai daya tarik wisata yang dikembangkan dengan pendekatan kon- 
servasi laut yang memanfaatkan karakter sumberdaya pesisir dan laut dengan tujuan olah raga di air/ pantai, seperti memancing,menyelam sambil melakukan pemotretan, kompetisi selancar, mendayung keliling melihat taman laut dengan pemandangan indah di permukaan air serta berbagai rekreasi perairan.

\section{Blue Ekonomi}

Blue ekonomi adalah ekonomi biru yang merupakan pendekatan ekonomi dipromosikan oleh Prof. Gunter Pauli, seorang financial engineer, pengusaha dan environmentalist. Blue ekonomi merupakan ekonomi biru tidak hanya mengarahkan upaya peningkatan nilai tambah melalui proses rantai produksi yang linear dan diversifikasi produk, namun juga pemanfaatan limbah proses produksi sebagai bahan baku produk turunan lain yang bernilai ekonomis, sehingga aktivitas industri akan semakin produktif, efisien dan zero waste karena bukanlah ekonomi kelautan tetapi sebuah sistem ekonomi yang diterapkan dalam upaya pembangunan kelautan dan perikanan Saad (2013).

Blue ekonomi atau Blue Economy is a collection of innovations contributing towards the creation of a global consciousness rooted in the search for practical solutions based on sustainable natural systems atau Istilah blue ekonomi merupakan sebuah paradigma (konsep) baru yang bertujuan untuk menghasilkan pertumbuhan ekonomi dari sektor kelautan dan perikanan, sekaligus menjamin kelestarian sumberdaya serta lingkungan pesisir dan lautan Nurhayati (2013). Tujuan Blue ekonomi Indonesia adalah mencapai pembangunan nasional secara meyeluruh dengan memberdayakan unsur-unsur yang berkaitan dengan Blue Economy dan tetap menjaga kelestarian laut Apriliani (2014).

\section{METODE PENELITIAN}

\section{Jenis Penelitian}

Jenis penelitian ini adalah jenis penelitian kualitatif. Pendekatan yang dilakukan pada penelitian ini adalah pendekatan Analisis konten. Penelitian ini bertujuan untuk merumuskan analisis konsep blue ekonomi pada pariwisata bahari di Pantai Jumiang Kabupaten Pamekasan.

\section{Sumber dan Pengumpulan Data}

Sumber data yang digunakan dalam penelitian adalah sumber data primer dan sumber data sekunder. Sumber data primer diperoleh dari observasi dan dokumentasi, sedangkan sumber data sekunder diperoleh dari berita, jurnal dan buku-buku yang relevan dengan penelitian ini. Sedangkan pengumpulan data yang digunakan penulis adalah observasi non partisipan Sugiyono (2009) dimana penulis hanya mengamati objek penelitian. Selain itu dalam pengumpulan data, penulis juga menggunakan dokumentasi dimana dokumentasi itu berupa gambar, tulisan dan foto yang ada di objek peneitian.

\section{Analisis Data}

Analisis data merupakan sebuah kegiatan untuk mengatur, mengurutkan, mengelompokkan, memberi kode/tanda, dan mengkategorikannya sehingga diperoleh suatu temuan berdasarkan fokus atau masalah yang ingin dijawab Gunawan (2013) . Terdapat tiga tahapan yang harus dikerjakan dalam menganalisis data penelitian kualitatif, yaitu Gunawan (2013):

1. Reduksi data adalah kegiatan meringkas, megelompokan hal-hal yang penting guna lebih mendekatkan penulis terhadap fokus yang diinginkan dan mencari tema dan polanya lebih jelas serta memudahkan untuk melakukan data. Reduksi data perlu dilakukankarena penelitian kualitatif biasanya memiliki banyak data pada observasi. Reduksi kata harus dilakukan secara terus menerus selama proses penelitian kualitatif berlagsung, dan saat penelitiannya telah menemukan kerangka konseptual, wilayah penelitian dan pendekatan data mana yang akan digunakan berarti reduksi data dalam penelitian tersebut sudah tampak.

2. Paparan data (data display) merupakan sekumpulan informasi tersusun, dan memberi kemungkinan adanya penarikan kesimpulan dan pengambilan tindakan.

3. Penarikan kesimpulan/verifikasi (conclusion drawing/verifying). Penarikan simpulan merupakan hasil penelitian yang menjawab fokus penelitian berdasarkan hasil analisis data. Simpulan disajikan dalam bentuk deskriptif objek penelitian dengan berpedoman pada kajian penelitian.

\section{HASIL DAN PEMBAHASAN}

\section{Konsep Pariwisata Bahari dan Blue Ekonomi}

Pariwisata Bahari atau wisata Pantai adalah salah satu bentuk pemanfaatan wilayah pesisir yang kegiatannya menitik beratkan pada daerah pantai dengan memanfaatkan sumberdaya alam pantai, baik yang berada di wilayah daratannya maupun wilayah perairannya Fandeli (2000) Wisata bahari adalah kegiatan untuk menikmati keindahan dan keunikan daya tarik wisata alam di wilayah pesisir yang memanfaatkan potensi alam bahari sumberdaya alam pantai, baik yang berada di wilayah daratannya maupun wilayah perairannya sebagai daya tarik wisata yang dikembangkan dengan pendekatan konservasi laut yang memanfaatkan karakter sumberdaya pesisir dan laut dengan tujuan olah raga di air/ pantai, seperti memancing, menyelam sambil melakukan pemotretan, kompetisi selancar, mendayung keliling melihat taman laut dengan pemandangan indah di permukaan air serta berbagai rekreasi perairan.

Blue Economy is a collection of innovations contributing towards the creation of a global consciousness rooted in the 
search for practical solutions based on sustainable natural systems atau Istilah blue ekonomi merupakan sebuah paradigma (konsep) baru yang bertujuan untuk menghasilkan pertumbuhan ekonomi dari sektor kelautan dan perikanan, sekaligus menjamin kelestarian sumberdaya serta lingkungan pesisir dan lautan Nurhayati (2013) . Tujuan Blue ekonomi Indonesia adalah mencapai pembangunan nasional secara meyeluruh dengan memberdayakan unsur-unsur yang berkaitan dengan Blue Economy dan tetap menjaga kelestarian laut Apriliani (2014).

\section{Konsep Blue Ekonomi Prespektif Islam dalam Pariwisata Bahari}

Kondisi geografis Indonesia yang merupakan sebuah negara kepulauan (Archipelagic country) yang memiliki sumberdaya perikanan dan kelautan yang melimpah mempunyai potensi yang besar untuk menjadi negara maju apabila Sumber Daya Alam (SDA) yang ada dikelola dan dikembangkan khusunya di sektor pesisir dan kelautan, hal ini perlu pemikiran kreatif dan inovatif bagaimana caanya untuk melestarikan sumbersumber daya laut, karena melesarikan sumer daya laut ini akan berdampak pada persediaan sumberdaya pangan masyarakat yang bisa diandalkan. Sumber daya laut Indonesia menjadi harapan banyak orang yang memiliki mata pencaharian di bidang perikanan dan kelautan seperti nelayan, para pengolah ikan, pengelola wisata bahari beserta usaha-usaha yang berhubungan dengannya seperti biro perjalanan, penginapan, pedagang cindera mata, dan sebagainya. Hal ini perlu adanya konsep blue ekonomi

Konsep Blue ekonomi merupakan konsep yang mendiskripsikan sebuah aktivitas ekonomi dengan minimalisir limbah akan tetapi tetap meningkatkan perekonomian masyarakat dengan menjadikan laut sebagai ekosistem yang dilindungi dan dioptimalkan kemanfaatannya dalam rangka meningkatkan ekonomi rakyat Apriliani (2014). Sehingga walaupun terdapat kegiatan Pariwisata bahari pemanfataan pesisir dan laut dapat dilakuakn dengan cara yang ramah lingkungan, berkelanjutan dan tampa minggalkan limbah dan sampah yang dapt merusak karakter dan bentuk pesisir dan laut tersebut. Karena pada dasarnya dalam al-Quran telah dijelaskan bahwa pada dasarnya manusia diciptakan di muka bumi hanya sebagai kholifah di muka bumi yang mempunyai kewajiban untuk menjaga lingkungan dari kerusakan alam khusunya yang dibuat oleh manusia sebagaimana firman Allah SWT pada Surat AL-Baqarah ayat 30

Artinya : "Ingatlah ketika Tuhanmu berfirman kepada para Malaikat: "Sesungguhnya Aku hendak menjadikan seorang khalifah di muka bumi." Mereka berkata: "Mengapa Engkau hendak menjadikan (khalifah) di bumi itu orang yang akan membuat kerusakan padanya dan menumpahkan darah, padahal kami senantiasa bertasbih dengan memuji Engkau dan mensucikan Engkau?" Tuhan berfirman: "Sesungguhnya Aku mengetahui apa yang tidak kamu ketahui." (QS. Al-Baqarah [2]: 30)
Ayat diatas menjelaskan bahwa manusia diciptakan untuk memelihara bumi agar bumi meliputi daratan dan lautan tetap terpelihara keaneka ragaman hayatinya dan dapat dimanfaatkan dengan sebaik-baiknya. Melalui ayat al-Qu'an pula Allah memerintahkan manusia untuk selalu memakmurkan bumi baik di daratan maupun dilautan sebagaiamana dalam ayat QS. Huud ayat 61 disebutkan bahwa :

Artinya: "Dan kepada Tsamud (Kami utus) saudara mereka shaleh. Shaleh berkata: "Hai kaumku, sembahlah Allah, sekalikali tidak ada bagimu Tuhan selain Dia. dia Telah menciptakan kamu dari bumi (tanah) dan menjadikan kamu pemakmurnya, Karena itu mohonlah ampunan-Nya, Kemudian bertobatlah kepada-Nya, Sesungguhnya Tuhanku amat dekat (rahmat-Nya) lagi memperkenankan (doa hamba-Nya)." (QS. Huud [11]: 61)

Ayat diatas lebih mengaskan lagi bahwa hakikatnya manusia di muka bumi wajib memakmurkan bumi melalui kegiatankegiatan ekonomi seperti meningkkan kagiatan pariwisata di pantai Jumiang Pademawu Pamekasan dengan konsep blue ekonomi agar lingkungan tetap terjamin bersih dan berkelanjutan sehingga sumber daya alam terus berkembang dengan baik agar pemanfataan pesisir dan laut dapat dilakukangan dengan ramah lingkungan, berkelanjutan dan tampa minggalkan limbah dan sampah yang dapat merusak karakter dan bentuk pesisir dan laut tersebut melalui konsep blue ekonomi.

Konsep blue ekonomi ini diharapkan dapat mengatasi problem pembangunan di wilayah pesisir dan laut terutama dalam menggerakkan potensi ekonomi seperti pariwisata bahari agar mampu membuka lapangan kerja, meningkatkan pendapatan dan kesejahteraan dengan namun tetap menjaga kelestarian lingkungan. Secara praktis, blue ekonomi adalah ekonomi yang dibangun atau digerakkan oleh aktivitas yang mengemisikan sedikit CO2 (low carbon), menggunakan SDA secara efisien (natural resources efficient), secara social hasilnyadapat dirasakan oleh semua rakyat dengan adil (socially inclusive), dan didukung oleh tekhnologi yang ramah lingkungan ( technology innovation ) Dermawan and Arif (2012). Dengan adanya pantai jumiang sebagai pariwisata bahari di kecamatan Pademawu masyarakat sekaitar akan merasa terbantu karena akan membuka lapangan kerja dan peluang usaha bagi masyarakat sekitar pesisir tentunya dapat meningkatkan pendapatan dan kesejahteraan masyarakat jumiang dengan harus sadar lingkungan dan mampu menjaga kelestarian lingkungan.

Oleh karena itu, dalam rangka mewujudkan pembangunan kelautan dan perikanan khusunya di sektor pariwisata yang berkelanjutan maka prinsip-prinsip blue ekonomi sangat penting untuk diintegrasikan dengan konservasi kelautan dan perikanan yang ramah lingkungan. Karena prinsip blue ekonomi adalah sebuah sistem ekonomi yang diterapkan dalam upaya pembangunan kelautan dan perikanan, secara umum prinsip-prinsip blue ekonomi mencakup:

1. Efisiensi pemanfaatan sumberdaya

2. Zero waste (tanpa limbah).

3. Social inclusiveness dan penciptaan lapangan kerja; 
4. Sistem produksi siklus, siklus generasi-regenerasitanpa henti, serta keseimbangan antara produksi dan konsumsi.

5. Pemanfaatan teknologi yang berasaskan hukum hukum fisika sebagai upaya adaptasi dengan kondisi alam dan sumberdaya lokal yang tersedia Saad (2013).

Pemanfa'atan sumber daya alam telah dijelasakan dalam alQur'an dalam firman Allah surah al-Baqoroh ayat 267 yiatu :

Artinya : hai orang-orang yang beriman, nafkahkanlah (di jalan allah) sebagian dari hasil usahamu yang baik-baik dan sebagian dari apa yang kami keluarkan dari bumi untuk kamu. dan janganlah kamu memilih yang buruk-buruk lalu kamu menafkahkan daripadanya, padahal kamu sendiri tidak mau mengambilnya elainkan dengan memincingkan mata terhadapnya. dan ketahuilah, bahwa allah maha kaya lagi maha terpuji (QS. al-Baqoroh ayat 267)

Ayat diatas menunjukkan bahwa sumber daya alam yang ada di bumi ini sangat baik apabila dimanfa'atkan dengan sebaik -baiknya sebagaiaman hadist Nabi Muhammad SAW yaitu

Artinya : "Manusia berserikat dalam tiga hal, yaitu air, padang rumput (lahan), dan api (energi)." (H.R. Abu Dawud)

Hal ini membuktikan bahwa padang rumput didiaratan atau hutan, air dilautan merupakan kepemilikan umum yang tidak boleh dimiliki secara individu. Lahan yang luas (hutan) disamakan dengan air dan api atau energi (termasuk barang tambang) dalam sektor kepemilikan umum yangmerupakan sumber daya alam yang bisa dikelola denga baik oleh manusia untuk dimanfa'atkan dalam kegiatan ekonomi seperti pengenlolaan pantai jumiang menjadi pariwisata bahari sebgai bentuk pengembangan ekonomi maysrakat pesisir dalam meningkatkan kehidupan ekonomi.

Kemduian dalam hal Zero waste (tanpa limbah) al-Qur'an juga menjelaskan bahwa hidup harus besih dan indah yaitu pada Q.S Al-Baqarah ayat 222

Artinya “... Sesungguhnya Allah menyukai orang-orang yang bertaubat dan menyukai orang-orang yang mensucikan diri." (QS. Al-Baqarah [2]: 222)

Dalam hadist disebutkan bahwa

Artinya : Sesungguhnya Allah swt. Itu baik, Dia menyukai kebaikan. Allah itu bersih, Dia menyukai kebersihan. Allah itu mulia, Dia menyukai kemuliaan. Allah itu dermawan ia menyukai kedermawanan maka bersihkanlah olehmu tempattempatmu. (H.R. at -Tirmizi: 2723)

Ayat dan hadist diatas menjelaskan bahwa sangat dianjurkan dalam islam untuk bersih dari sampah bahkan ada pahala tersendiri bagi orang-orang yang selelu mencintai kebersihan. Hal ini menunjukkan bahwa konsep blue ekonomi sebenarnya sudah ada dalam al-qur'an termasuk dalam hal Social inclusiveness dan penciptaan lapangan kerja islam sduah menjelaskan hal tesebut dalam ayat al-Qur'an

Artinya : dan Katakanlah: "Bekerjalah kamu, Maka Allah dan Rasul-Nya serta orang-orang mukmin akan melihat pekerjaanmu itu, dan kamu akan dikembalikan kepada (Allah) yang mengetahui akan yang ghaib dan yang nyata, lalu diberitakan-
Nya kepada kamu apa yang telah kamu kerjakan (Q.S Attaubah : 105).

Ayat diatas menjelaskan bahwa islam menganjurkan penciptaan lapangan kerja agar orang-orang dapat bekerja dengan baik agar perkembangan ekonomi menjadi tumbuh dan dapat mensejahterakan ummat manusia seperti halanya di daerah pesisir pantai jumiang dengan pariwisata baharai maka akan lebih meningkatkan ekonomi masyarakat sekitar dengan pelaung kerja yang ada.

Selanjutnya tentang keseimbangan antara produksi dan konsumsi yaitu islam sangat mengajarkan kepada ummatnya untuk hidup seimbang agar sesuai dengan porsi sehingga tidak terjadi pemborosan dalam hidup ayat al-Qur'an tentang larangan pemborosan yaitu dalam sura al-Isro' ayat 27 ialah:

Artinya : Sesungguhnya pemboros-pemboros itu adalah saudara-saudara syaitan dan syaitan itu adalah sangat ingkar kepada Tuhannya (Q.S Al-Isro')

Kemudian pada Surat Al-Maidah ayat 87-88

Artinya: (87) Hai orang-orang yang beriman, janganlah kamu haramkan apa-apa yang baik yang telah Allah halalkan bagi kamu, dan janganlah kamu melampaui batas. Sesungguhnya Allah tidak menyukai orang-orang yang melampaui batas (88) dan makanlah makanan yang halal lagi baik dari apa yang Allah telah rezekikan kepadamu, dan bertakwalah kepada Allah yang kamu beriman kepada-Nya.

Ayat diatas sangatlah jelas bahwa konsep blue ekonomi tentang keseimbangan antara produksi dan konsumsi ada dalam al-Qur'an yang selalu mengajarkan manusia untuk bersikap seimbang dan tidak boros.

Pemanfaatan teknologi yang berasaskan hukum-hukum fisika sebagai upaya adaptasi dengan kondisi alam dan sumberdaya lokal yang tersedia. Hal ini sudah dijelaskan dalam Al-Qur'an bahwa teknologi mempunyai peran yang sangat penting seperti halnya manusia mempunyai keinginan untuk keliling angkasa, maka manusia dianjurkan untuk mengembangkan ilmu pengetahuan dan teknologi sebagaimana dalam Surat Al-Mulk Ayat 19

Artinya: "Dan apakah mereka tidak memperhatikan burung-burung yang mengembangkan dan mengatup sayapnya diatas mereka? Tidak ada yang menahan di (udara) selain Yang Maha Pemurah Dia Maha Melihat Segala Sesuatu”. (QS. Al-Mulk: 19)

Dari penjelasan diatas maka dapat disimpulkan bahwa konsep blue ekonomi sudah lama dijelaskan dalam islam melalui al-Qur'an dan Hadist Nabi karena islam adalah agama yang kompleks dan rahmatan lil al-amin

\section{Implementasi Blue Ekonomi di Pantai Jumiang dalam pengelolaan Pariwisata Bahari}

Secara umum blue ekonomi mempunyai tujuan mencapai pembangunan nasional secara meyeluruh dalam kegiatan ekonomi dengan memberdayakan unsur-unsur yang berkai- 
tan dengan blue ekonomi dan tetap menjaga kelestarian laut. pariwisata bahari adalah salah satu dari berbagai jenis kegiatan ekonomi pariwisata dengan konsep laut dan pesisir sebagai objek dari wahana dan faislitas rekriasi. Seperti halnya di Pantai Jumiang Kecamatan Pademawu Kabupaten Pamekasan yang sudah menjadi wahana wisata pantai sehingga dapat disebut sebagai pariwisata bahari. Dengan adaya pariwisata bahari maka akan muncul kegiatan-kegiatan lainya yang apabila tidak di diberdayakan secara baik dan benar maka akan merusak lingkungan tersebut, hal ini terbukti banyaknya penggunaan sistem ekonomi dunia cenderung eksploitatif yang secara nyata telah merusak lingkungan.

Oleh karena itu konsep blue ekonomi menawarkan solusi dalam mengembangkan investasi dan bisnis yang leih baik dan menguntungkan baik dari segi ekonomi maupun lingkungan dengan cara menggunakan sumber daya alam lebih efisien dan tidak merusak lingkugan, sistem produksi yang lebih efisien dapat menghasilkan produk dan nilai ekonomi yang lebih besar serta meningkatkan penyerapan tenaga kerja local dan memberikan kesempatan untuk memberikan benefit kepada setiap contributor secara lebih proporsional dan adil. Dengan demikian konsep blue ekonomi bisa diartikan pertumbuhan ekonomi meningkat, rakyat sejahtera namun laut tetap biru.

Implematasi dari blue ekonomi dari aktivitas masyarakat pesisir di daerah sekitar pantai jumiang dalam kegiatan ekonomi pariwisata bahari yaitu

\section{Efisiensi Alam.}

Efisiensi pemanfaatan sumberdaya alam melalui peningkatan nilai tambah komodiras agar mampu menghasilakan manfaat ekonomi yang lebih banyak atau lebih besardengan menggunakan sumberdaya alam lebih hemat . dalam hal ini dapat dilakukan dengan cara:

Low CO2 Emission seperti penggunaan Pembangkit Listrik Tenaga Surya dalam penerangan agar dapat Untuk mengurangi emisi karbon. Atau aktivitas lain dalam pariwisata bahari diupayakan memanfaatkan sumber energi terbarukan

Resources Efficient artinya untuk memenuhi kebutuhan air minum dengan menghemat air tanah maka dibangun alat desalinasi air laut atau reverse osmosis (RO). Penggunaan bahan-bahan baku lokal dalam jumlah yang diperbolehkan, serta tidak melebihi batas maksimal penggunaan lahan daratan di sekitar pantai. Hal ini untuk meningkatkan efisiensi penggunaan sumberdaya alam

Efisiensi sumberdaya juga dapat dicapai melalui pemanfataan sumberdaya yang tersedia secara lokal, sehingga mampu mengurangi ketergantungan terhadap sumberdaya dari luar sebagai upaya peningkatan daya saing produk.

\section{Zero - Waste}

Zero waste atau prinsip tanpa limbah dan emisi berkaitan erat dengan upaya efisiensi sumberdaya alam karena dapat mendorong peningkatan efisiensi sumberdaya alam.
Sampah rumah tangga Anorganik juga bisa dijadikan sebagai bahan kerajinan tangan seperti Tas dan bunga atau fas Bunga yang jika dijual kepada pengunjung bisa menghasilkan uang bagi masyarakat sekitar. Ini secara tidak sadar sudah dilakukan oleh masyarakat sekitar yang telah membuatg tas dan bunga atau fas Bunga dari sampah yang telah dibuang oleh pengunjung dan masyarakat itu sendiri. Namun mereka tidak menjualnya secara jumlah yang besar karena kurangnya ptmahaman dan pengetahuan tentang menajeman pemasaran.

Inovasi dibutuhkan tidak hanya dalam teknologi pemanfaatan sumberdaya, tetapi juga dalam pengelolaan sampah dan limbah yang dihasilkanpenerapan prinsip 3R (reuse, reduce dan recycle) dalam pengelolaan sampah.

\section{Kepedulian Sosial}

Hal imi untuk memastikan bahwa kegiatan Pariwisata bahari nantinya berkontribusi terhadap peningkatan kesejahteraan masyarakat lokal secara merata, maka diperlukan adanya dukungan dan partisipasi dari setiap kelompok pemangku kepentingan. Untuk itu diperlukan adanya pemberdayaan masyarakat lokal yang mencakup sosialisasi program, penyadaran masyarakat, pelatihan keterampilan dan/ atau bimbingan teknis, pembentukan dan penguatan kelembagaan, pendampingan, bantuan peralatan penunjang, dan sebagainya. Dengan adanya program-program pengembangan mata pencaharian alternative yang dapat mendukung Pariwisata diharapkan dapat member nilai plus terhadap penyerapan tenaga kerja lokal. Sector ekonomi dapat memberikan kontribusi pada daerah dengan cara pemerintah daerah memberikan investasi dan perijinan serta penyerapan tenaga kerja (tour guide, dive guide, souvenir shop, boat operators, pegawai restoran, pegawai KJA, dll), pajak dan wisatawan local dan non local (tiket masuk, akomodasi, konsumsi, dll).

Multiple Revenue. Sebagai upaya peningkatan daya saing produk pariwisata bahari dapat mendorong peningkatan keragaman kegiatan ekonomi sehingga dapat menghasilkan multiple revenue, peningkatan pendapatan, dan perluasan lapangan kerja. Bisa saja satu orang penduduk pesisir bisa mendapat pendapatan yang banyak dari berbagai sumber pengasilan seperti dismaping mempunyai penyewaan kapal, masih mempunyai restourant atau masih mempunyai souvenir shop (modifikasi olahan ikan).

\section{KESIMPULAN}

Pariwisata Bahari adalah kegiatan untuk menikmati keindahan dan keunikan daya tarik wisata alam di wilayah pesisir yang memanfaatkan potensi alam bahari sumberdaya alam pantai, baik yang berada di wilayah daratannya maupun wilayah perairannya sedangkan blue ekonomi merupakan sebuah paradigma (konsep) baru yang bertujuan untuk menghasilkan pertumbuhan ekonomi dari sektor kelautan dan perikanan, sekaligus menjamin kelestarian sumberdaya serta lingkungan 
pesisir dan lautan

Konsep bule ekonomi sudah lama dijelaskan dalam islam melalui al-Qur'an dan Hadist Nabi karena Islam adalah agama yang kompleks dan rahmatan lil al-amin

Implematasi dari blue ekonomi dari aktivitas masyarakat sekitar Pantai Jumiang dalam kegiatan ekonomi pariwisata bahari yaitu

- Efisiensi Alam dapat dilakukan dengan cara Low CO2 Emission dan resources efficient

- Zero - Waste kegiatan yang tidak meninggalkan sampah.

- Kepedulian Sosial dengan adanya pemberdayaan masyarakat lokal yang mencakup sosialisasi program, penyadaran masyarakat, pelatihan keterampilan, pendampingan, dan sebagainya.

- Multiple Revenue. satu orang penduduk pesisir bisa mendapat pendapatan yang banyak dari berbagai sumber pengasilan.

\section{PENDANAAN}

Dari segi pendanaan, artikel ini murni di danai oleh penulis sendiri tanpa ada bantuan dari berbagai pihak, hal ini dikare-

\section{REFERENCES}

Apriliani, K. F. (2014). analisis potensi lokal di wilayah pesisir kabupaten kendal dalam upaya mewujudkan blue economy. Jurnal EDAJ 3.

Dermawan, A. and Arif, M. A. (2012). Pengembangan minawisata pulau-pulau kecil untuk mendukung implementasi blue economy . Jurnal KONAS VIII 22-24 Oktober.

Fadilah, S. and Suprihardjo, R. (2016). Pengembangan Kawasan Wisata Bahari Kecamatan Watulimo, Kabupaten Trenggalek. Jurnal Teknik ITS 5, 2337-3539. doi: 10.12962/j23373539.v5i1.11422.

Faisyal (2015). Motivasi Indonesia dalam Menerapkan Model Kebijakan Blue Economy Masa Pemerintahan Joko Widodo. Jurnal 1, 1915-1927.

Fandeli, C. M. (2000).

Gunawan, I. (2013). METODE PENELITIAN KUALITATIF.: Teori dan Praktik (Jakarta: PT Bumi Aksara).

Nurhayati, S. (2013). Blue and economy policyand their impact to indonesian community welfare. Jurnal Ekonomi dan Bisnis 12. nakan artikel ini dibuat bukan untuk diajukan untuk mendapatkan bantuan dari dari pihak kampus apalagi pemerintah (hibah, PDP ataupun yang lain).

\section{UCAPAN TERIMA KASIH}

Puji syukur kehadirat Allah SWT atas berkah limpahan rahmat dan karunia-Nya, sehingga penulis dapat menyelesaikan artikel ini dengan baik. Shalawat dan salam semoga selalu tercurah limpahkan kepada Nabi Muhammad SAW beserta keluarga dan pengikutnya.

Artikel ini juga tidak akan terselesaikan tanpa bantuan dari berbagai pihak yang memberikan dukungan semangat serta bantuan pendanaan sehingga penulis bisa menyelesaikan setiap tahapan penulisan artikel ini. Oleh karena itu, pada kesempatan ini penulis ingin menyampaikan terima kasih kepada Musoffan yang telah membantu ide-ide smartnya, Zaini yang telah menemani saat survey serta Ahmad yang juga menemani saat masuk dalam kawasan Pantai Jumiang. Terima kasih juga penulis sampaikan kepada pihak reviewer dan editor jurnal yang telah bersedia untuk mengoreksi tulisan ini.

Saad, S. (2013). pembangunan kelautan dan perikanan untuk kesejahteraan rakyat dan pembangunan nasional (Piadato Ilmiyah Direktur Jenderal Kelautan, Pesisir dan Pulau-Pulau Kecil Kementerian Kelautan dan Perikanan Republik Indonesia) (Malang).

Sugiyono (2009). Metode Penelitian Bisnis (Bandung, Alfabeta).

Conflict of Interest Statement: The author declare that the research was conducted in the absence of any commercial or financial relationships that could be construed as a potential conflict of interest.

Copyright (C) 2020 Fahrurrozi. This is an open-access article distributed under the terms of the Creative Commons Attribution License (CC BY). The use, distribution or reproduction in other forums is permitted, provided the original author(s) and the copyright owner(s) are credited and that the original publication in this journal is cited, in accordance with accepted academic practice. No use, distribution or reproduction is permitted which does not comply with these terms. 